\title{
ON THE METAMORPHOSIS OF ROCKS IN THE CAPE TOWN DISTRICT, SOUTH AFRICA.
}

\author{
Br Dr. R. N. Rubidae.
}

I gave, in a paper in the February number of the 'Geologist' a general view of the facts in the geology of this country which have led me to believe that the metamorphosis of rocks is due to a slow and gradual change in their constituents; of which change water is one of the čhief agents, and the internal heat of the earth not a necessary adjunct.

I now propose to describe more particularly those relations of the quartzite with the palæozoic rocks, a careful examination of which lhas rendered necessary an entire reconstruction of the geological map of the country. That map, published in the Transactions of the Geological Society, was the work of an able man, and the evidence on which the Devonian (Upper Silurian, Bain) was separated from the Clay-slate formation was (so far as I have been able to verify it), I believe, such, that he would not have been justified in coming to another conclusion by any generally admitted principle of the science; for this reason, I invite the criticism of European geologists on my facts and inferences, and their aid in solving many difficulties which still remain unexplained.

I stated in my former Paper that the plains and lower hills and valleys of the coast region, extending from Cape Town to the moutb of the Fish River, were formed of blue slaty and sandy rocks. These were all referred to one formation by Lichtenstein.

Dr. Krauss, an eminent botanist and geologist, states that he made repeated sections of the country, from the coast to the Karoo, and always found the clay-slate (Thonschiefer und Grauwackeschiefer) occupying the plains and valleys, and the quartzose sandstone or quartzite (Bunter-Sandstein) the mountains. On Zwartkops heights and the Von Stadens river bergen, he remarks this was notably the case. Dr. Atherstone, in a section through the district of George, could find no reason for separating the clay-slate from the Devonian. Mr. Bain agrees with these authorities as to the identity of the slates as far eastward as the mesozoic estuary of the Gamtoos river. In his map he shows the clay-slate, interrupted (as also mentioned by Krauss) by masses of granite, and surmounted by sandstones, extending from Cape Town to the edge of the mesozoic rocks, - a point corresponding to the Kabeljouw river's mouth in the sketch.

Lichtenstein, Bain, and Krauss therefore concur in believing the clay-slate and quartzite of the region between the Kromme and Kabeljouw rivers to be respectively identical and continuous with thuse of Cape Town, where the highly inclined beds of slate are surmounted by nearly horizontal sandstone. Mr. Bain, differing with the others, makes both cease here. I have little doubt of the continuity of the slate from Cape Town hither. I have none (as I shall presently 
show) of that of the Kromme and Kabeljouw region with those of the Zwartkops heights, and thence to the Fish River. Still, Mr. Bain is too able a man, and has generally too good reason for what he does, for any opinion of his to be passed over lightly. My own observations extend no further westward on this part of the coast than the region just mentioned; but as $I$ think $I$ can show that the relative positions of the quartzite mountain-ranges with the slate plains and valleys, clearly refer both to the like formations in the west, and as I have fossil and other evidence of their identity with the rocks further east, I will describe this region more fully.

The Kromme (winding) river runs for some miles from its source through a quartzite range, some few strata of slate here and there appearing in its bed; as, for instance, at the spot marked $A$ in the sketch, where the slate contained vegetable stems. The main direction of the range, Cougha and Baviaans Kloofbergen, is about north $80^{\circ}$ east. It sends off a branch, the Zitzi Komma (sometime called Kromme) heights, to Cape St. Francis, in direction north $44^{\circ}$ west: another, some of the spurs of which skirt Hermansdorp and Hankey, the main direction being north $79^{\circ}$ west. Thus these ranges diverge at an angle of about $35^{\circ}$; but, taking the spur, it would be nearer $60^{\circ}$. The Cougha bergen are, perhaps, 1500 to 1800 feet high ; the Zitzi Komma 1000 to 1300 . They are of quartzite sandstone of various degrees of hardness and crystalline character, often saccharine,

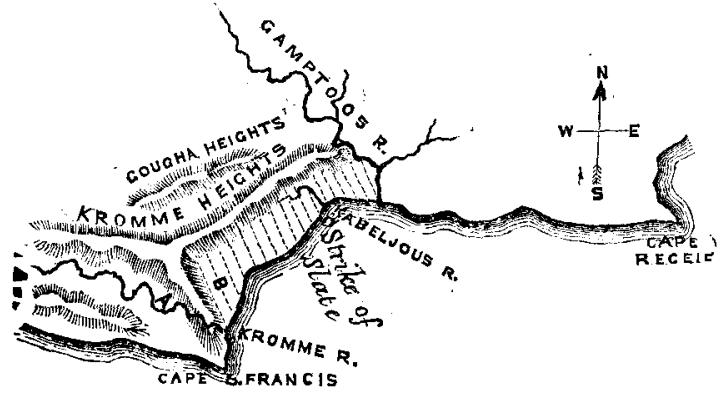

Plan of Country around St. Francts Bay.*

A. Spot in the Kromme river where fossils were found. B. Devonian fossils near this spot. C. Devonian fossils at Hermanisdorp. D. Devonian fossils at Kabeljouw river mouth.

sometimes ivory-like. The line subtending this angle, drawn from near the mouth of the Kromme to the most eastern portion of the Gamtoos below Hankey, would pass over scarce anything but slate; with a slight curvature it would pass over no quartzite. As the strike of the slate is north $66^{\circ}$ west, and the line nearly 15 miles long and making but a small angle with it, I believe the line would cross 12 miles of the strike. The dip of the rocks is considerable here; so

* The strike is too near perpendicular to the range of mountains, and the two ranges should have diverged at right angles. 
that I think six or seren geographical miles for the depth of the section is a low estimate. A glance at the sketch would show that a few miles on in the strike a parallel line would pass through nothing but quartzite.

The quartzite mountains, therefore, and their spurs, cross the slate at considerable angles to the strike of the latter, and the mountain ranges enclose large angular areas of slate. I have stated just now that two parallel lines could be drawn, at the distance of some miles apart, which should cut a corresponding portion of the strike of the slate. Taking the smaller spurs of the ranges, and giving the lines no very considerable curve, two such lines might be drawn within two miles of each other. My reason for dwelling on this relation will appear presently. I would now beg of any geologist who has followed me thus far to pause and reflect on these relations of the slate and quartzite, and before proceeding to answer to himself, and if not too great a favour, to me, through the 'Geologist,' the following questions :-

1st, Supposing the relations just described to be correctly represented,* is it not clear that Mr. Bain and the other authorities quoted are right in classing the slates with the old rocks, and making the quartzite a newer and independent formation?

2nd, If the geologist should find rocks resting conformably on the same quartzite, would he not refer them (same postulate) to a much newer formation than the slate?

This is simply what Mr. Bain has done.

I will suppose it admitted that the clay-slate of the region between the Kromme and the Kabeljouw and Gamtoos rivers is probably of identical and continuons formation with that of Cape Town, and that of the quartzose rocks which cross it at various angles to its strike, are continuous and identical in character with those of Table Mountain. Then I think it will not be disputed that these slates must have been upheaved into their present positions long ere the deposisition of the quartzose sandstone or its assumption of its present condition, which Darwin attributes to the infiltration of silica.

Let us now see what grounds we have for forming a judgment as to the age of these slates, reminding the reader that $\mathrm{Mr}$. Bain, from sections which I believe to be mainly correct, referred them to an epoch long preceding the Lower Silurian, which strata, resting on the quartzite, are supposed Upper Silurian (Devonian of European geologists), and rocks interstratified with like quartzite at the Maitland Mines and the eastern province generally are called Carboniferous.

Some time after the relations of the quartzite with the palæozoic and metamorphic rocks, observed in Namaqualand and in this province, had led me to predict that the former, throughout the colony, would be found to belong to one formation, Mr. Niven, of Jeffreys Bay, undertook, at my request, to search for fossil evidence bearing

* I have borrowed the pencil of a friend, Mr. R. Miller, to represent these relations more clearly to the eye. It is doubtful if the relation of the strike will be understood. 
on this question. He soon discovered Phacops Kafer, Orthis palmata, Spirifer antarcticus, two species of Strophomena, and several of Encrinites, which clearly established the Devonian character of the slates about the mouth of the Kabeljouw river. Last year, in a professional journey to those parts, I was fortunate enough to find fossils in the bed of the Kromme river (a), near Diep river $(b)$, and at Hermansdorp, which, together with the section, show that all these slates, supposed to be so ancient, were Devonian throughout. At different periods the discovery of the same species at Coxeomb, in Winterhoek, at Chatty, and Naroo, and a few weeks ago near Van Stadensberg, has clearly proved the identity of the palæozoic strata in the eastern province as far as the Fish River's mouth with the clayslate of the region I have described, and almost certainly of Cape Town.

Now, the quartzite of the Cougha range is continuous with that of the Coxcomb, and both are so with the Van Stadensberg. I could give a sketch of very nearly the same relations of these ranges with the slate as those described, but they are not quite so well marked. The directions of the ranges of quartzite hills, as shown on any map of the colony, with the explanation that the strike differs not very considerably throughout the province, will render this unnecessary. The quartzite ought then to be newer than the Devonian in the Eastern province also. Yet in this province it has never been regarded by any geologist as otherwise than conformable with the Devonian (Carboniferous; Bain). Dr. Atherstone and I believe that of the Cougha as equally conformable with the Devonian slates of the Kromme, Kabeljouw, and Gamtoos. The relations of the mountain chains $I$ have shown to be the same in both provinces.

I will now quote authorities to show that the conformability is unmistakeable in this province. If some of the extracts are long, it must be attributed to my belief that this is the most important part of my argument. If I can convince geologists that mountains 1200 to 3000 feet or more in beight, which take the direction in reference to the strike, which, as I have said, any map of the enlony will show they do take, are really composed of quartzose sandstone conformable, and at their junctions, and in valleys, interstratified with the Devonian slates they thus cross; it will, I think, be admitted that the rocks of this country (of different ages) have been subjected to a metamorphic action of a peculiar nature, and which bas not received sufficient attention. ${ }^{*}$

Bain.-Carboniferous System. This system differs but little, lithologically, from the quartzose sandstones of the Silurian ranges of

* In explanation of the great desire 1 have always felt for the opinions of European geologists of uote on the subject of these relations of our roch, I must remark, that I am quite a self-tanght geologist, and have had no experience in any country but this. Moreover, all the colonial geologists, while admitting the relations described, see nothing inexplicable by admitted theories in them. Dr. Atherstone, for instance, believes that the quartzose sandstones were originally deposited in the positions mentioned, interstratified with the slates. Mr. Bain believed them of different and unconformable formation: so does Krauss. Since he has seen the Devonian fossils, Mr. Bain is inclined to think

VoL. $\mathrm{r}$. $3 \mathrm{~B}$ 
the western parts of the colony (except that the carboniferous rocks have no pebbles). The quartzose sandstone, which is in general characteristic of this system, passes into chloritic schist at De Stade's and Van Staden's rivers, where mines of galena and copper have been for some time worked, but I fear not profitably.

"No workable coal has yet been discovered in this system; but numerous species of carboniferous plants have been found near the Kowie River, Woest's Hill, Slowison's Poort, and other localities in the talcose schist."- 'Eastern Province Magazine,' vol. i. p. 456, Godlonton and White, Graham's Town. Compare with maps and description of strata, Geol. Trans.

Dr. Atherstone.- "Above the quartzose and micaceous sandstones and chloritic schists at the Maitland mines, and also along the Lorie River to Hankey, and still further on in the Gamtoos River, a dark grey fine-grained magnesian limestone is found.... Above this limestone in some places, as at the Maitland Mines, Van Staden's River, and the Luorie River, there is a hard and coarse sandstone with quartz pebbles, which makes excellent millstones.... Below the magnesian limestone lie conformably quartzose sandstones and micaceous shales and schists, similar to those of the carboniferous sandstones of the Zeurberg. The sandstones and schists of the Coxcomb and Winterberg range appear more like the Old Red Sandstone formation, and are infinitely more contorted than the carboniferous rocks; and as no fossils have as yet been found in them,* and the range appears

the slates and quartzites couformable, and that he has made a mistake in the boundary of the formation in the east, while he strongly affirms the accuracy of his section in the west.

It will be seen by reference to former Papers, that ou my belief in the truth of Mr. Bain's section I founded the prediction that the clay-slate and Devouian would be proved one formation. When I use the word Devonian as applying to all our strata, I would explain that I make no pretension to settle the question of their age ou my own autbority, or to deny the possibility of there being strata as old or older than the Cambrian or older rocks in Britain. I simply mean that I have seen no reason for believing in any older rock unconformable with the Devonian; and I hope I have shown that the position of the quartzite, with reference to the latter, is the same as it is to the clay-slate, which Bain and Wylie believe so much older.

I ask for the aid I mention because I think the opinion of high authority wouid be of great value to us by showing what is regarded as credible, and what is not. The assistantsecretary of the Geological Society, some years ago, told me that the story of quartzite metamorphosis was rejected in toto. I hope the labours of Messrs. Sorby, Daubrée, Hunt, and others, have somewhat modified opinions. At the period in question my belief in this assimilation of rocks of different ages had not been confirmed by those discoveries which rendered the map published by the Society entirely obsolete as to some of the principal formations of the Colony. It was quite natural that under such circumstances the frlfilment of my early prediction should have been regarded as the confirmation of lucky guesses; but when I pointed out the fact that as to the Carbouiferous and clay-slate formations, the result of my researches was, as I have said, to render the map obsolete, I think that in taking no notice of my communications the Society lost an opportunity.

* The discovery of Devonian fossils at the northern foot of the Coxcomb, in rocks with but a slight inclination, and that of the same species close to the Van Stadensberg, in beds with a dip of $46^{\circ}$, with a clear section connecting them with the schists at the De Stade's River mines, is singular in connectiou with this remark of my friend, and would seem to indicate that he has been misled as to the relative ages of formations in the east, in the same manner as Mr. Bain has further west. 
continuous with the Zwarteberg range, which I believe to be Devonian, I should consider them also of the same age."-Ibid., pp. 585587.

Mr. Wylie, Government Geological Surveyor.- "Here" (at Goobeloan's northern base of the Zeurberg) "the shales disappear, and we enter upon rocks exactly the same as the Wittenbergen and the Koroo Poort sandstones in the western district. These continue all the way through the Zeurberg. Beside the yellowish or brownish sandstones there are many beds of very sandy shale, usually of a bright colour. Many of the sandstones cannot be distinguished from those of Table Mountain, though the latter are of much older date."*

"The sandstones of the Zeurberg form a great anticlinal arch; but this consists again of three great folds and two or more minor flexures. The beds may be seen dipping at all angles from $5^{\circ}$ to $80^{\circ}$. On the seaward side of the Zeurberg, between the 20th and 21 st milestones, $I$ again crossed the trap conglomerate on the southern side of the anticlinal. It there forms a belt in width about 500 yards, and in actual thickness is not more than 500 or 600 feet. Grey shales occur both above and below it." - 'Notes of a Journey,' etc., Cape Town, Saul, Solomon, \& Co. (See also p. 3 of the same, and passim.)

There may be some little apparent confusion arising out of the different nomenclature used by the authorities I have quoted. The fact is, that the beds which are usually blue and clayey schists, with some argillaceous sandstones, are generally altered to a micaceous chloritic or talcose character, and in the upper part, when mixed with the sandstones, are ochry. The spots in which Devonian fossils have been found, together with the uniformity of
strike, prove their identity throughout. strike, prove their identity throughout.
This is now admitted by all observers as to this province.

The sections sent herewith are:-

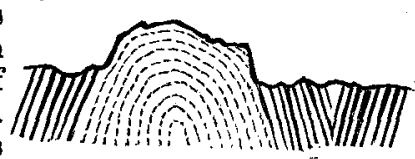

Fig. 1. - Section of Pickel Vontein. (Atherstoue and Rubidge.)

1. Pickel Vontein, carefully observed by Dr. Atherstone and myself. 2. Chatty, measured by Mr. Pinchin and myself. 3. Section through Klein Poorden Poort, by Mr. Pinchin and myself. These have been merely sketched without measurement in the present instance, as I am unfortunately deprived of Mr. Pinchin's valuable aid. A carefully executed section was sent home to the Geological Society some years ago.

I will conclude this paper by showing that Fig. 2.-Section through Chatty. what I have, I hope, satisfactorily proved of (Pinchin and Rubidge.) the quartzite, is also predicable of crystalline limestone or marble--viz. the continuity of horizontal beds unconformable with the subjacent strata, with beds of the same kind intercalated between the latter.

* Mr. Wylie, in his section of this part of the Colony, which, though not published, is placed in the 'Town Hall, in Cape Town, makes the shales above spoken of conformable with the sandstones. 
I have described saccharine and finer-grained quartzites in this relation. I have now to mention that at Rodos, sixty miles from

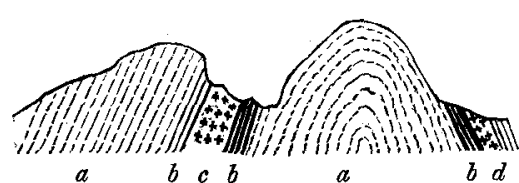
the mouth of the Orange River, strata of limestone rest in extensive masses on the mountains, I was told, horizontally; while $b$ beds of Fig. 3.-Section throngh Klein Poorden Poort, rieties of crystalline limestone (Pinchin and Rubidge.) $a a$, quartzite; $b b b$, slate; $c$, porphyry (Bain); gneiss. $d$, porphyry.

I should hardly have thought it necessary to contest the igneous origin of marble at the present day, had I not seen in your Magazine the account of a recent experiment.

SOME ACCOUNT OF BARRETTIA, A NEW AND REMARKABLE FOSSIL SHELL FROM THE HIPPURITE LIMESTONE OF JAMAICA.

\section{By S. P. Woodward, F.G.S.}

The fossil represented in the accompanying figures is one of that kind whose discovery severely tests the faith of the uaturalist in his previous conclusions, and may appear to raise a suspicion not only respeeting the sufficiency of his data, but even as to the correctness of his method of investigation. Almost any person, at first sight of the specimen, would think he was looking at a coral, and it would seem like an attempt to impose on one's credulity to say it was a bivalve shell, like an oyster or a clam.*

Yet there is no doubt it is a kind of Hippurite, although the rays give it a novel and extraordinary character. The discoverer had quite satisfied himself on this point before he brought it to England and placed it in our hands. It was found last year (January, 1861), by Mr. Lueas Barrett, F.G.S., Director of the Geological Survey of the British West Indies, in the parish of Portland, in the north-east of

* This is not the only case of the sort. The genus Goniophyllum, one of the "Zoantharia rugosa," established by Milne-Edwards, is apparently identical with Calceola, the well-known bivalve fossil of the Eifel, placed by Lamarck with the "Radistes," and admitted as a Brachiopod, with a sign of doubt, by Mr. Davidson and myself. Goniophyllum pyramidale is a scarce fossil of the Upper Silurian at Dudley and Malvern, but not uncommon in the Baitic island of Gothland. It was deseribed as a Calceola by Girard in 1842. Another species, which is so like Calceola sandalina that Murchison and Verneuil assumed the existence of Devonian strata in Gothland, on the strength of its occurrence, has small rootlets of attachment along the borders of its "hinge-area," and a vesicular interior, like Cystiphyllum. After carefully cxamining a series of examples belonging to $M$. Lindström, of Wisby, we ean only say that they are probably neither Brachiopoda nor Zoantharia, although very like each in some respects. 